\title{
LEVELS AND DISTRIBUTION OF POLYBROMINATED DIPHENYL ETHERS IN VARIOUS TISSUES OF FORAGING HENS FROM AN ELECTRONIC WASTE RECYCLING AREA IN SOUTH CHINA
}

\author{
Shu-Xuan Liang, $\dagger$ Qian Zhao,$\dagger$ Zhan-Fen Qin, $\neq$ Xing-Ru Zhao, $*$ Zhong-Zhi Yang, $\ddagger$ and Xiao-Bai Xu $\ddagger$ \\ $\dagger$ College of Chemistry and Environmental Science, Hebei University, Baoding, Hebei, 071002, China \\ $\ddagger$ State Key Laboratory of Environmental Chemistry and Ecotoxicology, Research Center for Eco-environmental Sciences, \\ Chinese Academy of Sciences, Beijing, 100085, China
}

(Received 28 September 2007; Accepted 2 January 2008)

\begin{abstract}
Levels and distribution of polybrominated diphenyl ethers (PBDEs) in various tissues of hens foraging near an electronic wastes stack spot in Taizhou, China, were studied. With high-resolution gas chromatography/negative chemical ionization mass spectrometry analysis, 37 PBDE congeners from di- to hepta-brominated and BDE 209 were identified and quantified in the liver, heart, skin, fat, intestine, muscle, blood, oviduct, ovum, gizzard, spleen, and kidney tissues of hens. Based on lipid weight in all analyzed tissues, muscle exhibited the highest PBDE concentrations (17,977 ng/g lipid wt), BDE 209 was the dominant congener, and the sum of quantified PBDEs followed the order muscle $>$ fat $>$ intestine $>$ heart $>$ liver $>$ oviduct $>$ gizzard $>$ blood $>$ skin $>$ ovum. Principal component analysis results indicated that the hen muscle tissue was characterized by BDE 32, 209, 28, and 75 congeners; hen intestine, heart, and blood tissues were characterized by BDE 153, 99, 183, 138, 154, 47, and 100 congeners; and hen skin, liver, oviduct, ovum, gizzard, spleen, kidney, and fat tissues had a similar PBDE congener profile. The present study also indicated that the PBDE congeners were persistent enough to accumulate through the human food chain and that deca-BDE might be potential risk to ecoenvironment.
\end{abstract}

Keywords-Polybrominated diphenyl ethers Electronic wastes Hen Tissue Taizhou

\section{INTRODUCTION}

Polybrominated diphenyl ethers (PBDEs), including penta$\mathrm{BDE}$, octa-BDE, and deca-BDE, which constitute the majority of commercial PBDE products, are extensively used as brominated flame retardants in plastics, textiles, electronic appliance, building materials, and other materials [1]. They can enter the environment during production, use, disposal, and recycling processes [2]. Now PBDE congeners have been detected in abiotic media [3], wildlife [2], and humans [4]. Because of their potentially toxic characteristics [5], the penta- and octa-BDE commercial mixtures had been banned in European Union and several U.S. states [6]. At present, deca-BDE is the only commercial PBDE product that is still allowed for use as brominated flame retardants in many polymers. The bromine science environmental forum estimated the total world market demand for the commercial PBDEs by region in 2001 and found that deca-BDE makes up approximately $83.2 \%$ [7].

In China, deca-BDE is the dominant formulation, and it is widely used in electronic appliances; it has also been reported that approximately one-fourth of the electronic waste in China was from Japan [8]. In 2004, the Basel Action Network and Greenpeace China investigated the recycling of electronic waste in the Taizhou region of China, and they found that electronic waste was being smuggled by container ships from Japan [9]. Tasaki et al. [10] reported that deca-BDE was used in the rear covers of television sets beginning in 1987 and continuing through 1990 in Japan. These television sets have a 9.8-year average lifetime, and exported in new and old televisions for reuse and recovery.

The limited studies conducted by Chinese researchers showed that BDE 209 was one of the dominant PBDE congeners in the

* To whom correspondence may be addressed (zhaoxr@craes.org.cn).

Published on the Web 1/25/2008. sample media, such as air [11], sediment [12], milk, and blood [13]. The available data from other countries indicated that BDE 209 had been detected in some raptor species tissues or eggs with modest concentration [14]. In the analyzed tissue of predatory birds, muscle and liver had the highest PBDE lipid weight concentration [15]. The determined bird samples in most studies were wildlife species, but the relative bird species for the human food and the PBDE distribution in various tissues of those birds are infrequently investigated.

The edible foraged hens were collected near an electronic waste stack spot in Taizhou in May 2006. The electronic wastes were comprised mainly of waste television sets that were shipped from Japan. Approximately six years ago, workers separated the usable materials from the waste televisions, then shattered the electronic trash into powder; finally, they stacked them on a riverbed and covered them with soil. Now, many vegetables grow on it, but some areas were bared by the weather. In the present study, we analyzed 37 PBDE congeners in 12 hen tissues, including liver, heart, skin, fat, intestine, muscle, blood, oviduct, ovum, gizzard, spleen, and kidney, to investigate the PBDE level and distribution in various tissues of hens and the potential value for risk assessment.

\section{MATERIALS AND METHODS}

\section{Chemicals}

The standard solution of BDE-AAP-A15X for accuracy and precision was obtained from Accustandard (New Haven, CT, USA). It was also employed to spike matrix for initial precision and recovery studies and ongoing precision and recovery following analytical method. The injection internal stock solution EO5275 was purchased from Cambridge Isotope Laboratories (Andover, MA, USA). Decabromodiphenylether was purchased from the laboratories of Dr. Ehrenstorfer (Augsburg, Germany). The 
Table 1. The wet-, dry-, and lipid-weight data of the hen tissues ( $\mathrm{g}$ )

\begin{tabular}{lccccccccccccc}
\hline & Liver & Heart & Skin & Fat & Intestine & Muscle & Oviduct & Gizzard & Ovum & Blood & Spleen & Kidney \\
\hline Wet & $-\bar{a}^{\mathrm{a}}$ & 4.915 & 5.000 & 1.000 & 9.698 & 7.547 & - & - & - & 10.000 & 0.834 & 1.700 \\
Dry & 2.000 & 1.302 & 2.000 & 0.968 & $\overline{-}$ & 2.000 & 2.000 & 2.000 & 2.000 & 2.000 & - & - \\
Lipid & 0.316 & 0.025 & 1.528 & 0.887 & 0.233 & 0.060 & 0.164 & 0.421 & 1.058 & 0.030 & - & - \\
\hline
\end{tabular}

${ }^{a}$ Data not obtained.

internal standard polychlorinated biphenyl (PCB) 209 was obtained from ChemService (West Chester, PA, USA).

$n$-Hexane, methylene dichloride, toluene, methyl alcohol, acetone, and nonane are pesticide grade purchased from Tedia (Fairfield, OH, USA). Anhydrous sodium sulfate, sulfuric acid, sodium hydroxide, and silver nitrate are analytical grade (Beijing Chemical Factory, Beijing, China). Anhydrous sodium sulfate was activated for $6 \mathrm{~h}$ at $660^{\circ} \mathrm{C}$ and stored in desiccators. Silica gel (100-200 mesh, Qingdao Haiyang Chemical, Shandong, China) was rinsed with methanol followed by dichloromethane, baked at $40^{\circ} \mathrm{C}$ for a minimum of $5 \mathrm{~h}$, activated for $6 \mathrm{~h}$ at $550^{\circ} \mathrm{C}$, and stored in desiccators. The column contained alternating layers of neutral, acid, basic, and silver nitrate silica gel $(200 \times 18$-mm inner diameter $)$ used for sample cleanup.

\section{Samples preparation and extraction}

Twelve tissues were excised directly after euthanasia of the hens, including the liver, heart, skin, adipose tissue, intestine, muscle, oviduct, ovum, gizzard, spleen, and kidney. All the tissues were cleaned with deionized water, wrapped in precleaned aluminum foil, and transported to the laboratory with an ice bag, then stored at $-20^{\circ} \mathrm{C}$ until analyzed. Before extraction the tissues were dry frozen and homogenized with anhydrous sodium sulfate. They were then spiked with $1 \mathrm{ng}$ of PCB 209 and equilibrated for $24 \mathrm{~h}$ before extraction. In order to facilitate comparison, the wet-, dry-, and lipid-weight data of various tissues are shown in Table 1 . The tissues were Soxhlet extracted with $200 \mathrm{ml}$ of hexane/dichloromethane (1: $1, \mathrm{v} / \mathrm{v}$ ) for 18 to $24 \mathrm{~h}$, then the extracts were divided into two parts. One part followed by evaporation to dryness, and the gravimetric lipid determination was performed (the spleen and kidney were not analyzed). Another part was cleaned up with a multilayer silica gel column packed from the bottom to top, with $2 \mathrm{~g}$ silver nitrate silica gel, $1 \mathrm{~g}$ activated silica gel, $3 \mathrm{~g}$ basic silica gel, $1 \mathrm{~g}$ activated silica gel, $4 \mathrm{~g} 44 \%$ acid silica gel, $4 \mathrm{~g} \mathrm{22 \%}$ acid silica gel, $2 \mathrm{~g}$ activated silica gel, and 1.5 $\mathrm{g}$ anhydrous sodium sulfate. The PBDE mixture was eluted with $70 \mathrm{ml}$ of $n$-hexane:dichloromethane (1:1), and the final extract volume was reduced to $20 \mu \mathrm{l}$ under a gentle purity $\mathrm{N}_{2}$ stream. A known amount (1 ng) of internal standard (EO-5275) was added to all extracts prior to instrumental analysis. Throughout the extraction, cleanup, and analysis procedure, the analytes were protected from light by wrapping the containers with aluminum foil or by using amber glassware.

\section{Chemical analysis}

Polybrominated diphenylethers were analyzed with an Agilent model 6890N gas chromatographer coupled with a model 5973i mass spectrometry (Agilent Technologies, Palo Alto, CA, USA) using negative chemical ionization in the selected-ion monitoring mode. The gas chromatography column was DB-5MS fused silica capillaries ( $15 \mathrm{~m}, 250-\mu \mathrm{m}$ inner diameter, $0.25-\mu \mathrm{m}$ film thickness). The injector and interface temperature were 275 and $300^{\circ} \mathrm{C}$, respectively, and samples were injected in the pulsed splitless mode (345 kPa). Methane was used as the chemical ionization moderating gas and helium as the carrier gas at a flow rate of $1.5 \mathrm{ml} / \mathrm{min}$. Both the ion source and quadrupole temperatures were $150^{\circ} \mathrm{C}$. The temperature program was from $80^{\circ} \mathrm{C}$ (held for $1 \mathrm{~min}$ ) to $200^{\circ} \mathrm{C}$ at $10^{\circ} \mathrm{C} / \mathrm{min}$ and then from 200 to $300^{\circ} \mathrm{C}$ (held for $15 \mathrm{~min}$ ) at $20^{\circ} \mathrm{C} / \mathrm{min}$.

For sample analysis, the ion at $\mathrm{m} / \mathrm{z}, 79 / 81$ was the base peak for mono-BDE to hepta-BDE congeners and $\mathrm{m} / \mathrm{z}, 486.7$ and 488.7 for BDE 209 only. The base peak at $\mathrm{m} / z, 79$ and 486.7 was chosen for quantification. The EO-5275 ( $\mathrm{m} / \mathrm{z}, 302,304,372,374)$ and PCB $209(\mathrm{~m} / \mathrm{z}, 496,498)$ were used for quality control of the whole procedure but could not be used for quantification because of a high dispersion of the response factors detected for the different bromination degree. Therefore, quantification was performed by external standard with recovery correction.

\section{Quality assurance/quality control}

From sample collection to chemical analysis, the proper handling was adopted to avoid the potential sample contamination, cross contamination, and PBDE degradation. Prior to analysis of the samples, the initial precision and recovery were carried with clean fish tissue (the relative standard deviation was lower than $10 \%$ ), and the method quality control was done by regular analysis of procedural blanks and ongoing precision and recovery (the relative standard deviation was lower than $15 \%$ ). Instrumental quality control was done by regular injection of solvent blanks and standard solutions. Quantification was performed by external standard calibration, and results were corrected by the recovery factor. The efficiency/capacity of the method was demonstrated by isotope dilution highresolution mass spectrometry and analyzing the certified reference materials WMF-01 (reference fish tissue for organic contaminant analysis, Wellington Laboratories, Wellington, New Zealand), and satisfaction results were obtained.

Recoveries between 74 and $120 \%$ were obtained for the majority of the congeners, with the exception of the three mono-BDE congeners, which had recoveries from 30 to $50 \%$ because the vapor pressure of these compounds is the highest among the mixture. This may induce losses of mono-BDE during the extraction and concentration procedure. Therefore, in the present study we did not analyze mono-BDE in tissues. A procedural blank and ongoing precision and recovery were run in parallel with every batch of six samples. The amounts of PBDEs in the procedural and the field blanks were well under $10 \%$ of the levels found in the analyzed samples, so no corrective action was taken. The limit of detection was based on the peak-to-peak noise of the baseline near the analytic peak obtained by analyses of a spiked sample (the ratio of signal to noise was 3 ). The limits of detection of individual PBDEs were different in same samples, and the same congener in different matrix had different limit-of-detection values.

\section{Data analysis}

Data were further evaluated with principal components analysis. Based on the concentration of individual PBDE con- 


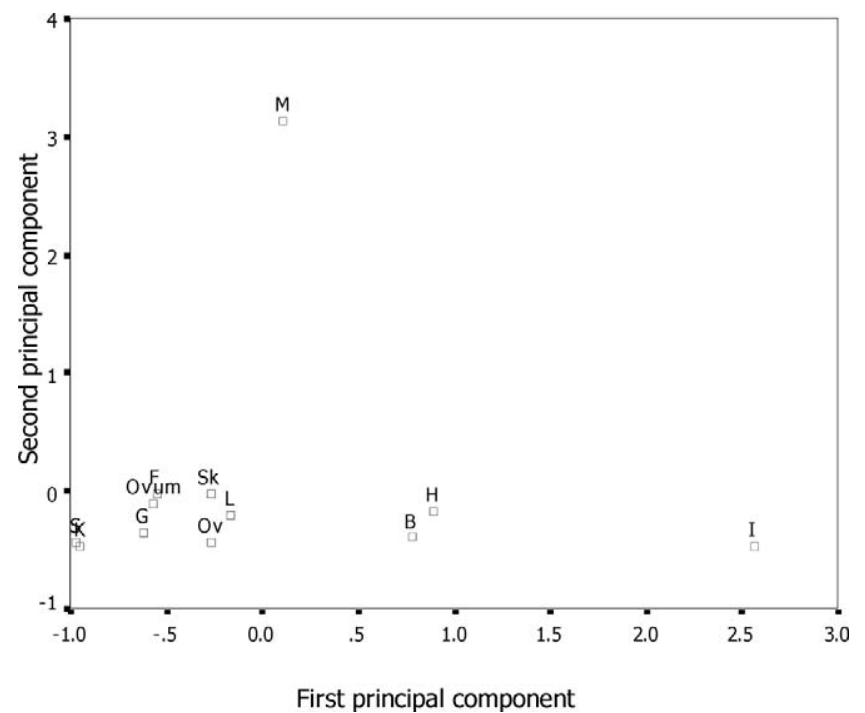

Fig. 1. Two-dimensional principal component score plot obtained from the data correlation matrix of 12 tissues of foraged hens from electronic waste recycling area in South China. Tissues are marked by their specific code: $\mathrm{S}=$ spleen; $\mathrm{K}=$ kidney; $\mathrm{G}=$ gizzard; Ovum = ovum; $\mathrm{F}=$ fat; $\mathrm{Sk}=$ skin; $\mathrm{Ov}=$ oviduct; $\mathrm{L}=$ liver; $\mathrm{B}=$ blood; $\mathrm{H}$ $=$ heart; $\mathrm{I}=$ intestine; $\mathrm{M}=$ muscle.

geners, the individual PBDE congeners were treated as variables, and the 12 hen tissues were treated as cases. The PBDE congeners detected in less than half the analyzed tissues were removed. The eigenvectors were normal-varimax rotated to improve the interpretability of the results. Statistical analyses were carried out with SPSS 12.0 for Windows ${ }^{\circledR}$ Release 12.0 (SPSS, Chicago, IL, USA). The score plots obtained from the first two principal components are shown in Figure 1. Principal component 1 accounted for $53 \%$ of the variance of the data set and was positively determined by BDE 153, 99, 183, 138, 154,47 , and 100 congeners; principal component 2 accounted for $33 \%$ of the total variance and was characterized by BDE 32, 209, 28, and 75 congeners (Fig. 2).

\section{RESULTS AND DISCUSSION}

\section{Levels of PBDEs in various tissues of hens}

Table 2 shows the PBDE lipid concentrations on wet weight except for the spleen and kidney tissues. In the various tissues analyzed, brominated diphenyl ethers $7,8,10,11,12 / 13,15$, $17 / 25,28 / 30,31,32,35,37,47,49,66,71,75,77,85,99$, $100,116,118,119,126 / 155,138,153,154,166,181,183$, 190 , and 209 were identified and quantified. The results indicated that BDE 209 was the dominant congener, and BDE 71 was not detected in any of the analyzed tissues. Based on lipid weight (Table 2), muscle had the highest PBDE concentrations $(17,977 \mathrm{ng} / \mathrm{g}$ lipid wt), and ovum had the lowest (125 ng/g lipid wt). The highest and lowest concentrations of the sum of quantified PBDE congeners except for BDE 209 were found in the intestine ( $323 \mathrm{ng} / \mathrm{g}$ lipid wt) and gizzard (33 $\mathrm{ng} / \mathrm{g}$ lipid wt). The concentrations of quantified PBDEs showed the order muscle $>$ fat $>$ intestine $>$ heart $>$ liver $>$ oviduct $>$ gizzard $>$ blood $>$ skin $>$ ovum. Compared to other reported studies, the ovum PBDE level (125 ng/g lipid wt) was much higher than that in eggs $(2.6 \mathrm{ng} / \mathrm{g}$ lipid wt) in Belgium market basket [16] and much lower than the mean levels in peregrine falcon eggs in Sweden (4,000 ng/g lipid wt) [14]. The liver PBDE level (587 ng/g lipid wt) was lower than that

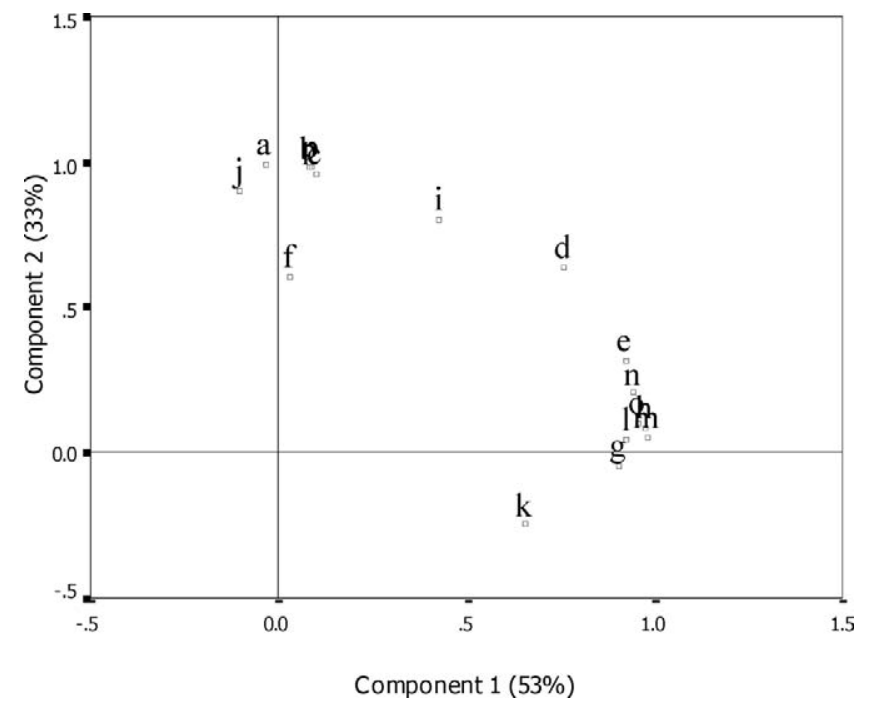

Fig. 2. Two-dimensional principal component loading plot obtained from the data correlation matrix of 12 tissues of foraged hens from electronic waste recycling area in South China. Polybrominated diphenyl ethers (PBDEs) congener identification: (a) BDE 32; (b) BDE 28; (c) BDE 75; (d) BDE 49; (e) BDE 47; (f) BDE 66; (g) BDE 100; (h) BDE 99; (i) BDE 118; (j) BDE 85; (k) BDE 155; (1) BDE 154; (m) BDE 153; (n) BDE 138; (o) BDE 183; (p) BDE 209.

in the common kestrel liver (12,200 ng/g lipid wt, Beijing), but the muscle tissue was in the same grade [17]. Voorspoels et al. [15] also reported the same trend that the sum of quantified PBDE congeners (except for BDE 209) level in muscle was higher than that in the liver.

\section{Principal component analysis and congener profiles}

Principal component analysis (PCA) provides an informative visual display, facilitating intertissue comparisons. The score plots (Fig. 1) indicated that hen muscle tissue was characterized by BDE 32, 209, 28, and 75 congeners; hen intestine, heart and blood tissues were in positive position with BDE $153,99,183,138,154,47$, and 100 congeners. This is probably due to different metabolism capacities in various tissues.

The PCA results also indicated that hen muscle, liver, oviducts, ovum, gizzard, kidney, spleen, and fat had a similar PBDE congener profile. In most analyzed tissues, the three higher PBDE (except for BDE 209) congeners had the trend BDE $47>99>153$, and the phenomenon was similar to that in other studies [18]. But in skin and intestine tissues, the trends were BDE $99>47>153$, it also had been found in adipose tissues of the Switzerland sparrowhawk [2].

The lower, di- and tribrominated PBDE congeners were nearly not detected in liver, heart, intestine, blood, kidneys, and spleen tissues. It may be due to the low brominated congeners that were easily eliminated or the higher brominated congeners that were less easily debrominated to di- and tribrominated congeners. As for the low level of di- and tribrominated congeners in fat, it might be due to their low hydrophobicity. The amount di- and tribrominated congeners that were detected in skin, muscle, oviduct, and ovum tissues might be explained by the fact that the low brominated congeners have lower vapor tension, are abundant in the atmosphere, and can be readily exchanged between atmosphere and skin. It is also possible that the efficient metabolism in muscle tissues was lower than others or that the PBDEs can be excreted via oviduct and ovum during spawning. 


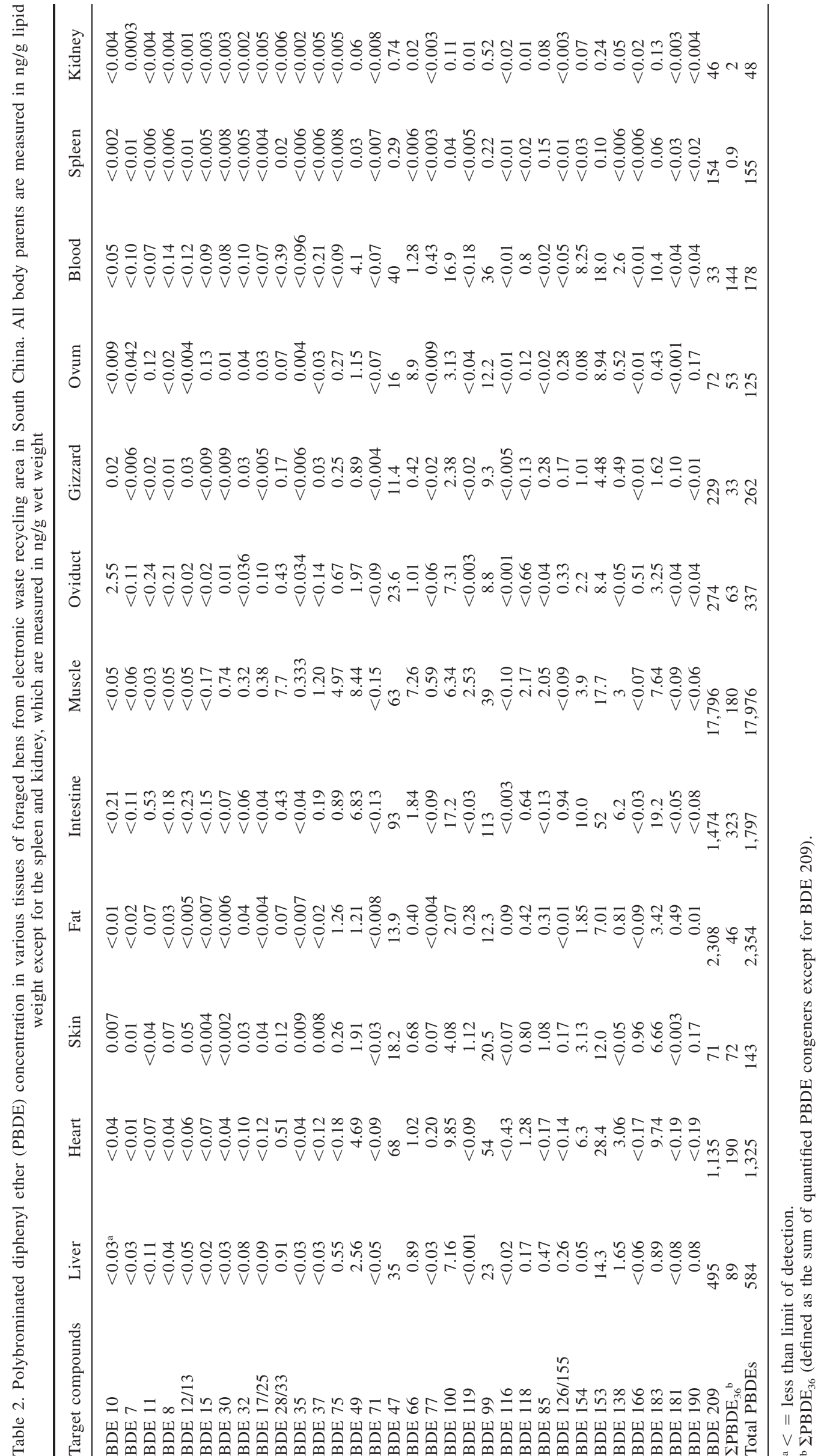




\section{BDE 209}

Previous studies reported that BDE 209 could be degraded to low brominated congeners that were more bioavailable and toxic $[19,20]$. Stapleton et al. $[19,20]$ suggested that parent PBDEs could be debrominated to lower brominated congeners in the intestinal tract of the common carp. Morck et al. [21] also observed that metabolic processes in the intestine of rats dosed orally by decabrominated diphenyl ethers were induced either by cytochrome P450 enzymes in the intestine wall or by intestinal microflora. Viberg et al. [22] concluded that BDE 209 had neurotoxic effects in mammals. Therefore, deca-BDE might be a potential risk to ecoenvironment.

Boon et al. [23] reported that higher brominated PBDEs did not biomagnify, likely because of their high molecular weights or sizes and subsequent inefficient dietary uptake in fish [23]. But recently published data suggest that the higher brominated congeners may indeed bioaccumulate (e.g., peregrine falcon) [14]. The results of the present study showed that BDE 209 was detected in all samples analyzed and was the dominant congener. Its concentration ranged from 33 to $17,796 \mathrm{ng} / \mathrm{g}$ lipid weight and in spleen and kidney ranged from 46 to $154 \mathrm{ng} / \mathrm{g}$ wet weight. Compared with the other analyzed birds tissues [15,17], muscle tissue showed the highest BDE 209 concentration, but liver and blood BDE 209 concentrations were among the lowest or lower than the other studies.

In the present study, the BDE 209 distribution in various tissues showed the trend muscle $>$ fat $>$ intestine $>$ heart $>$ liver $>$ oviduct $>$ gizzard $>$ ovum $>$ skin $>$ blood (based on lipid wt). A higher ratio of BDE 209 to the sum of all PBDEs analyzed was found in muscle $(99 \%)$ and spleen $(99.4 \%)$, but in blood it was only $18.84 \%$. This might be due to the different bioaccumulation potentials or metabolism rates of the individual PBDE congeners. Although BDE 209 was the dominant congener in various tissues, PCA results showed that muscle was the only tissue characterized by BDE 209. On the other hand, the high levels of BDE 209 in the environmental compartments such as the atmosphere, water, and sediment have been determined in South China [3,12]. We also detected PBDEs in the air, water, soil, animal, and vegetable samples around the electronic waste and found the similar PBDE congener profile (X.R. Zhao et al., unpublished data). The PBDE levels were $967 \mathrm{pg} /$ $\mathrm{m}^{3}$ in air, $201 \mathrm{ng} / \mathrm{L}$ in field water, $28 \mu \mathrm{g} / \mathrm{g}$ dry weight in soil, from 16 to $687 \mathrm{ng} / \mathrm{g}$ wet weight in eight species of animals, and from 195 to $9,502 \mathrm{ng} / \mathrm{g}$ dry weight in 18 species of vegetables, respectively. The dominant PBDE congener was BDE209 in different compartments. Also, the higher level of PBDEs in muscle tissues was found in environment and exposure samples [15,24]. Therefore, muscle tissue may be used as a good indicating matrix to estimate the PBDE contamination in the environment, but further study is needed.

Acknowledgement-The present study was supported by grants from the Knowledge Innovation Program of Chinese Academy of Sciences (KZCX2-YW-420-3) and the National Science Foundation of China (20437020 and 20677074).

\section{REFERENCES}

1. van Esch G. 1994. Brominated diphenyl ethers. Environmental Health Criteria 162. World Health Organization, Geneva, Switzerland.

2. Naert C, Van Peteghem C, Kupper J, Jenni L, Naegeli H. 2007. Distribution of polychlorinated biphenyls and polybrominated diphenyl ethers in birds of prey from Switzerland. Chemosphere 68:977-987.

3. Chen SJ, Gao XJ, Mai BX, Chen ZM, Luo XJ, Sheng GY, Fu
JM, Zeng EY. 2006. Polybrominated diphenyl ethers in surface sediments of the Yangtze River Delta: Levels, distribution and potential hydrodynamic influence. Environ Pollut 144:951-957.

4. Johnson-Restrepo B, Kannan K, Rapaport DP, Rodan BD. 2005. Polybrominated diphenyl ethers and polychlorinated biphenyls in human adipose tissue from New York. Environ Sci Technol 39: 5177-5182.

5. Kemmlein S, Herzke D, Law RJ. 2003. BFR-governmental testing programme. Environ Int 29:781-792.

6. Hale RC, Alaee M, Manchester-Neesvig JB, Stapleton HM, Ikonomou MG. 2003. Polybrominated diphenyl ether flame retardants in the North American environment. Environ Int 29:771-779.

7. Law RJ, Allchin CR, de Boer Jacob, Covaci A, Herzke D, Lepom P, Morris S, Tronczyski J, de Wit CA. 2006. Levels and trends of brominated flame retardants in the European environment. Chemosphere 64:187-208.

8. Hileman B. 2002. Electronic waste: Concern grows over what to do with the massive amounts of electronic products discarded each year. Chem Eng News 80:15-18.

9. Hileman B. 2006. Electronic waste: States strive to solve burgeoning disposal problem as more waste ends up in developing countries. Chem Eng News 84:18-21.

10. Tomohiro T, Takumi T, Masahiro O, Sakai S. 2004. Substance flow analysis of brominated flame retardants and related compounds in waste TV sets in Japan. Waste Manag 24:571-580.

11. Chen LG, Mai BX, Bi XH, Chen SJ, Wang XM, Ran Y, Luo XJ, Sheng GY, Fu JM, Zeng EY. 2006. Concentration levels, compositional profiles, and gas-particle partitioning of polybrominated diphenyl ethers in the atmosphere of an urban city in South China. Environ Sci Technol 40:1190-1196.

12. Mai BX, Chen SJ, Luo XJ, Chen LG, Yang QS, Sheng GY, Peng PG, Fu JM, Zeng EY. 2005. Distribution of polybrominated diphenyl ethers in sediments of the Pearl River Delta and adjacent South China Sea. Environ Sci Technol 39:3521-3527.

13. Bi XH, Qu W, Sheng GY, Zhang WB, Mai BX, Chen DJ, Yu L, Fu JM. 2006. Polybrominated diphenyl ethers in South China maternal and fetal blood and breast milk. Environ Pollut 144: 1024-1030.

14. Lindberg P, Sellström U, Häggberg L, de Wit CA. 2004. Higher brominated diphenyl ethers and hexabromocyclododecane found in eggs of peregrine falcons (Falco peregrinus) breeding in Sweden. Environ Sci Technol 38:93-96.

15. Voorspoels S, Covaci A, Lepom P, Jaspers VL, Schepens P. 2006. Levels and distribution of polybrominated diphenyl ethers in various tissues of birds of prey. Environ Pollut 144:218-227.

16. Voorspoels S, Covaci A, Neels H, Schepens P. 2007. Dietary PBDE intake: A market-basket study in Belgium. Environ Int 33:93-97.

17. Chen D, Mai BX, Song J, Sun QH, Luo Y, Luo XJ, Zeng EY, Hale RC. 2007. Polybrominated diphenyl ethers in birds of prey from Northern China. Environ Sci Technol 41:1828-1833.

18. Lam JC, Kajiwara N, Ramu K, Tanabe S, Lam PK. 2007. Assessment of polybrominated diphenyl ethers in eggs of waterbirds from South China. Environ Pollut 148:258-267.

19. Stapleton HM, Letcher RJ, Baker JE. 2004. Debromination of polybrominated diphenyl ether congeners BDE 99 and BDE 183 in the intestinal tract of the common carp (Cyprinus carpio). Environ Sci Technol 38:1054-1061.

20. Stapleton HM, Letcher RJ, Li J, Baker JE. 2004. Dietary accumulation and metabolism of polybrominated diphenyl ethers by juvenil carp (Cyprinus carpio). Environ Toxicol Chem 23:1939-1946.

21. Morck A, Hakk H, Orn U, Klasson Wehler E. 2003. Decabromodiphenyl ether in the rat: Absorption, distribution, metabolism, and excretion. Drug Metab Dispos 31:900-907.

22. Viberg H, Fredriksson A, Jakobsson E, Örn U, Eriksson P. 2003. Neurobehavioural derangements in adult mice receiving decabrominated diphenyl ether (PBDE 209) during a defined period of neonatal brain development. Toxicol Sci 76:112-120.

23. Boon JP, Lewis WE, Tjoen-a-choy MR, Allchin CR, Law RJ, de Boer J, Ten Hallers-tjabbes CC, Zegers BN. 2002. Levels of polybrominated diphenyl ether (PBDE) flame retardants in animals representing different trophic levels of the North Sea food web. Environ Sci Technol 36:4025-4032.

24. Van den Steen E, Covaci A, Jaspers VL, Dauwe T, Voorspoel S, Eens M, Pinxten R. 2007. Accumulation, tissue-specific distribution and debromination of decabromondiphenyl ether (BDE 209) in European starlings (Sturnus vulgsris). Environ Pollut 148:648-653. 